\title{
Cytological Demonstration of An XO Sex-Mechanism in Males of Tecticeps japonicus, An Isopod Crustacea
}

\section{Hidejiro Niiyama}

Faculty of Fisheries, Hokkaido University, Hakodate, Japan

Received October 4, 1955

A considerable amount of work has been done on the chromosomes of the isopod Crustacea, it being possible to refer to many papers such as : those on Oniscoidea by Nichols ('02, '09), Mir ('39), Radu ('30), Vandel ('26, '28, '34, '41) and Imai \& Makino ('40); on Asellota by Carnoy ('85), Dworak ('35), Vandel ('38, '41), Staiger \& Bocquet ('54) and Sugiyama ('33); on Valvifera by Nichols ('09); on Epicaridea by Hiraiwa ('36) and on Flabellifera by Callan ('40). Two papers among them have dealt with the cytological demonstration of the sex-determination mechanism in isopods, though a great deal of discussion has been offered on the question of the sex mechanism by several authors. Dworak ('35) was the first to report an XO-mechanism in males of Asellus aquaticus. Recently, Staiger and Bocquet ('54) have described female heterogamety in four closely related species of Jaera marina (Janiridae, Asellota). The present author has found a clear-cut evidence of male heterogamety of an XO-mechanism in Tecticeps japonicus Iwasa. The X-chromosome of the species is clearly distinguishable from others because of its large size and precocious migration in the first division, as described in the following pages.

The author is greatly indebted to Professor Sajiro Makino for his helpful suggestions and for going through the manuscript.

\section{Material and method}

Tecticeps japonicus Iwasa (Sphaerominae, Sphaeromidae, Flabellifera) is one of the marine isopods. It is $10-15 \mathrm{~mm}$ in body length. They are common around the sea-shore of the Hokkaido and the Kurile Islands. The material upon which the present study was based was obtained from the animals collected in the vicinity of the Akkeshi Marine Biological Station, Hokkaido in June and July in the years, 1950 to 1954. The testes situated under the carapase being connected by a pair of white vas deference were removed by vivisection and fixed in the modified weak Flemming's mixture. Sections were cut 10 micra thick and stained with Heidenhain's iron-haematoxylin.

\section{Observations}

The spermatogonium. The testes of the present species consist of three pairs of testicular lobes, each having a spindle shape. The terminal parts of 
the testicular lobes are occupied by spermatogonial cells and the others are filled with cells at various stages of maturation. The dividing figures of
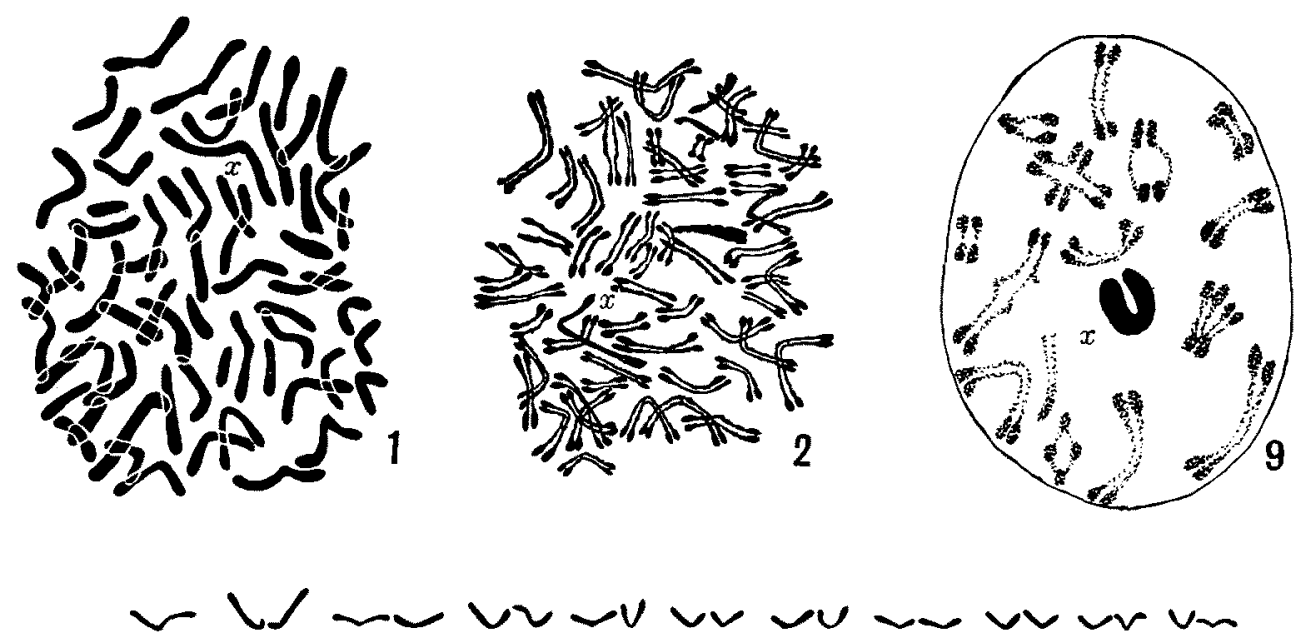

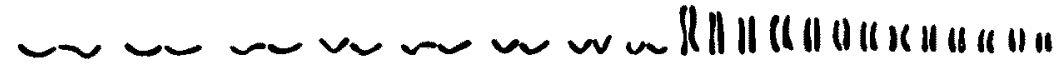
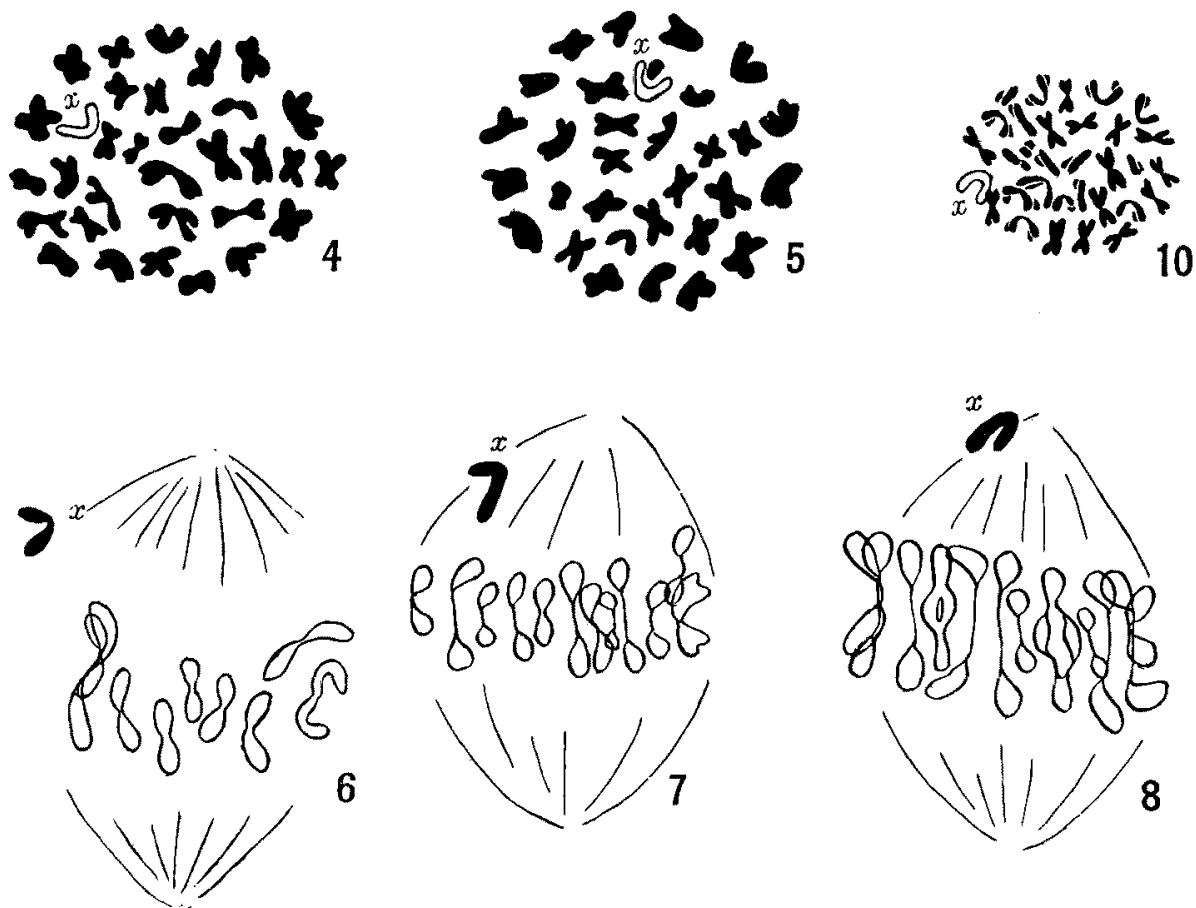

Figs. 1-10. Chromosomes of Tecticeps japonicus Iwasa. 1-2. Metaphase chromosomes of spermatogonia, 62 autosomes and an $x$-chromosome in each. $\times 3700.3$. Serial alignment of the paired chromosomes from Fig. 1. $\times 1800.4-5$. Polar view of metaphase chromosomes of primary spermatocyte, 31 tetrads and an $\mathrm{x}$-chromosome in each. $\times 3700$. 6-8. Side view of metaphase chromosomes of primary spermatocyte. $\times 3700.9$. Nucleus in diakinesis stage, indicating an $\mathrm{x}$-chromosome in deep black. $\times 3700$. 10. Metaphase chromosomes of secondary spermatocyte containing an $\mathrm{x}$-chromosome. $\times 3700$. 
spermatogonial cells are not frequent, the metaphase figures being rather rare. Examples of excellent metaphase plates are shown in Figures 1 and 2. After careful counting of the chromosomes in several such plates, it was found that the diploid number was invariably 63 . It is quite natural to expect the existence of a single X-chromosome from the occurrence of the odd chromosome number in the spermatogonial division. The spermatogonial chromosomes are dimorphic in complex; the complex consists of certain numbers of acrocentric and metacentric chromosomes. As seen in Figure 3 which is a serial alignment of the supposed pairs of chromosomes, there are 18 pairs of acrocentric chromosomes of rod-type, 13 pairs of metacentric ones of $\mathrm{V}$ - and $\mathrm{J}$-shape, and a single, large metacentric element. The latter is very conspicuous among the others in that it is the largest of all in size, submedian in fibre attachment, and unpaired without homologous mate. This finding is explicable only by assuming this element as the X-chromosome.

Primary spermatocyte. The majority of germ cells are found in process of meiosis in the testicular lobes fixed in June and July. The first and second divisions were available for study in the material collected in approximately the first week of July.

The primary spermatocytes in the metaphase side view clearly and invariably show remarkable precocious migration of a $\mathrm{V}$-shaped chromosome of outstandingly large size, in striking contrast to the autosomal bivalents which constitute the equatorial plate. This element which makes the precocious migration to one of the poles is in all probability the $\mathrm{X}$-chromosome because of its characteristic feature as seen in the former division and of its particular
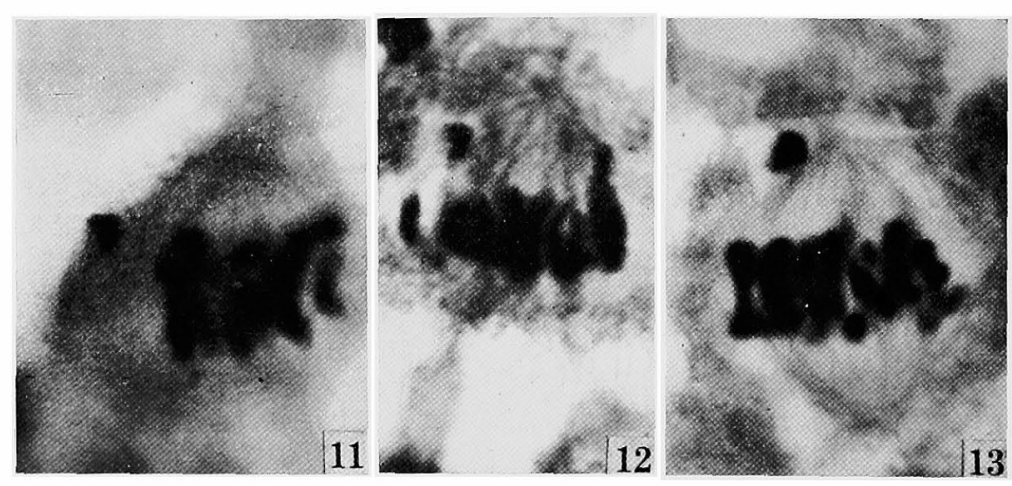

Figs. 11-13. Microphotographs of side view of metaphase chromosomes of primary spermatocyte, showing the precocious migration of the $x$.

$11,12,13$ corresponding to $6,7,8$ respectively. $\times 2000$. behaviour com. mon to the $\mathrm{X}$ of many other animals (Figs. 6, $7,11,12, x)$. In the early anaphase stage (Figs, 8, 13) this element reaches one of the poles, while the autosomal elements are on

the way thereto. Apparently this element is univalent in structure.

The number of bivalents observed in equatorial plate is 31 without exception. In addition to these autosomal bivalents, the X-chromosomes makes its appearance when the focus of the microscope is changed a little upward or downward from the equatorial plate, being very conspicuous for its large $\mathrm{V}$-shaped, univalent configuration. In the first meiotic division the $\mathrm{X}$-element 
moves to one of the poles without division, resulting in the production of two kinds of secondary spermatocytes, one having the $\mathrm{X}$ and the other containing no such one.

Observations of the diakinetic nucleus revealed that one large element has remained in a heteropycnotic condensation showing a distinct $\mathrm{V}$-shape. This is no other than the X-element (Fig. 9).

Thus the $\mathrm{X}$-chromosome of this form is characterized by a distinguishable $\mathrm{V}$-shape and large size, remarkable precocious separation in the first meiotic division and heteropycnosis in the growing stage.

The chromosome constitution of the primary spermatocyte is shown by the formula, $32=31+\mathrm{X}$.

Secondary spermatocyte. As results of the first division, it is evident that there are to be produced two kinds of secondary spermatocytes, the Xclass cell containing the X-element and the non-X-class cell. The present material furnished a few dividing secondary spermatocytes in which an X-class cell was observed (Fig. 10). It contained 31 autosomal dyads and a large $\mathrm{V}$-shaped chromosome which is an X-element.

\section{Discussion}

In reference to the literature so far published, there are two papers which deal with the sex chromosome of isopods. Dworak ('35) has reported an XOmechanism of sex-determination in males of Asellus aquaticus. According to her descriptions, the diploid number of the species was 17 , comprising 10 $\mathrm{V}$-shaped and 7 rod-shaped chromosomes. In the first division the X-chromosome goes to one of the poles ahead the others. Sometimes one or two bivalents passed precociously to the poles. In the polar view, therefore, the number of chromosomes varies from 7 to 9 in number. In the spermatogonial metaphase, the X-chromosome appeared as a rod-shaped one, but in the first division it assumed a round, thick and condensed form with a bivalent configuration. To the present author's knowledge and experience, the X-chromosome designated by Dworak in the primary spermatocyte is no other than a tetrad which seemed mechanically to be separate from the equatorial plate, due probably to distortion of spindle fibres influenced by fixation. Vandel's opinion concerning the work of Dworak is that the statement of Dworak about the finding of an XO-mechanism in males of Asellus aquaticus is probably erroneous. Vandel ('38), on the other hand, reported in the same species the diploid number of 16 and the haploid number of 8 , and showed that the result of Dworak ('35) were not fully trustworthy.

The second paper on the sex chromosomes of isopods was published by Staiger and Bocquet ('54), who claimed the occurrence of female heterogamety in four closely related marine species of the Jaera marina (Janiridae, Asellota). Their description deals mainly with $J . m$. forsmani; in the first meiotic division of females there are 8 bivalents and a particular element 
with a trivalent configuration. The trivalent is formed by the pairing of each of the two arms of a metacentric chromosome with an acrocentric element. The two acrocentrics, which are of different size, have always been found to be co-oriented at metaphase. The metacentric chromosome is connected with them by terminal chiasmata, as happens in most bivalents. The diakinetic nucleus of the male shows 9 bivalents without any sign of structural heterozygosity. The trivalent configuration in females therefore represents a sex trivalent similar to that found in male meiosis of several species of animals (e.g., mantids, Drosophila miranda, and marsupials). The sex chromosome mechanism of Jaera marina is of the $\mathrm{XY}_{1} \mathrm{Y}_{2}$-type, the females being heterozygous. The sex trivalent of a similar nature has been found in all four members of the Jaera marina superspecies so far studied.

The present author feels that the statement of Staiger and Bocquet concerning female heterogamety is not fully conclusive, since their conclusion was derived from the study of only the metaphase side-view of primary oocyte and diakinetic nuclei of males. Any determinative statement must be postponed until investigations have been completed on the diploid and haploid chromosomes of both sexes.

In striking contrast to the above cases, the X-chromosomes of the present species is rather clear-cut. The data of the present study may be sufficient to justify the statement that male heterogamety exists in this form, on the basis of the following points: 1) the chromosome number found in the spermatogonium is always odd, showing an unpaired V-shaped chromosome of outstandingly large size, 2) the diakinetic nucleus shows a heteropycnotic body which is closed V-shaped, corresponding to the unpaired element, 3) the metaphase plate of every primary spermatocyte shows a large $V$-shaped element passing precociously to one of the poles, and 4) some of the secondary spermatocytes contain a large $\mathrm{V}$-shaped element. The several peculiarities as noted above are quite sufficient to allow one to accept the unpaired element of large $\mathrm{V}$-shaped as the X-chromosome.

So far as the Crustacea are concerned, male heterogamety was cytologically established in several orders, such as in Decapoda by Niiyama, '37, '38, '41, in Amphipoda by Niiyama '50, in Copepoda by Heberer, '32, in Ostracoda by Bauer, '34, '40, and in Phyllopoda by Baker and Rosof, '27, '28 and Rey, '34. The evidence of female heterogamety reported in Jaera marina by Staiger \& Bocquet ('54), though it is not fully conclusive, furnishes the sole example in the Crustacea, so far as the recorded cases are concerned.

\section{Summary}

1. The spermatogonium contains 63 chromosomes. In the serial alignment of the paired chromosomes a single V-shaped chromosome of outstandingly large size remains unpaired. The chromosome constitution of the spermatogonium comprises 62 autosomes and an X-element. 
2. At diakinesis the $\mathrm{X}$-chromosome appears as a heteropycnotic body.

3. The primary spermatocyte metaphase always shows $\mathrm{V}$-shaped $\mathrm{X}$ chromosome migrating precociously to one of the poles.

4. Some of the secondary spermatocytes contain an X-chromosome of large $\mathrm{V}$-shape.

5. On the basis of the above facts, it is apparent that the present species shows male heterogamety represented by an X-O mechanism.

\section{Literature cited}

Baker, R. C. and Rosof, J. A. 1927. Spermatogenesis in Brachypus vernalis. I. The testis and spermatogonial divisions. Ohio Journ. Sci. 27.

- 1928 a. Spermatogenesis in Brachypus vernalis. II. The spermatocyte. Ohio Journ. Sci., 28.

- 1928 b. Spermatogenesis in Brachypus vernalis. III. Secondary spermatocyte, spermatid, and spermatozoon. Ohio Journ. Sci. 28.

Dworak, I. 1935. Maturation des cellules sexuelles mâles et structures, cytoplasmiques dans la spermatogénèse chez l'Asellus aquaticus. Folia Morphologia, V.

Heberer, G. 1932. Die Spermatogenese der Copepoden. Zeits. wiss. Zool. 182.

Imai, G. and Makino S. 1940. The chromosomes of Porcellio scaber Latreille (Isopoda, Oniscidae). Jap. Journ. Genet. 16.

Mir, C. 1939. Le nombre de chromosomes des Ligiidae. C. R. S. A. Sci. 209.

Niiyama, H. 1937. The problem of male heterogamety in the decapod Crustacea, with special reference to the sex-chromosomes in Plagusia dentipes de Haan and Eriocheir japonicus de Haan. Journ. Fac. Sci. Hokkaido Imp. Univ., Ser. VI, Zool. 5.

- 1938. The X-Y chromosomes of the shore-crab, Hemigrapsus sanguineus de Haan. Jap. Journ. Genet. 14.

- 1941. The X-O type of sex-chromosome found in Ovalipes punctatus (de Haan). Jap. Journ, Genet. 17.

- 1950. The X-Y Mechanism of the sex-chromosome in the male of Annisogammarus annandalei (Tatteisall) (Crustacea. Amphipoda). Ann. Zool. Jap. 23.

Palmer, R. 1925. The chromosome cycle of Gammarus chevreuxi Sexton. Nature 116.

- 1926. The chromosomes complex of Gammarus chevreuxi Sexton. I. Spermatogenesis. Q.J.M.S. 70.

Radu, V. 1930. The spermatogénèse chez Armadillidium opacum. C. R. S. B. 105.

- 1931. Spermatogeneza la Armadillidium vulgare Latr., cu privire speciala asupra evolutiei chromatinei si a constituantilor cytoplasmatici. Mem. Sect. Stiintif. Acad. Romania, Ser. III, VIII.

Rey, P. 1934. La Formule chromosomiale de Daphnia pulex de Geer. Bull. Soc. Zool. de France 59.

Staiger, H. and Bocquet, Ch. 1954. Cytological demonstration of female heterogamety in Isopods. Experientia X/2.

Sugiyama, M. 1933. The spermatogenesis of Asellus nipponensis. Journ. Fac. Sci. Tokyo Imp. Univ., Ser. IV, 3.

Vandel, M. A. 1926. Triploidie et parthénogenèse ches 1'Isopodde, Trichoniscus (Spiloniscus) provisorius Rocovitza. C.R.A.S. 183.

- 1928. La parthénogenèse géographique. Contribution á l'étude biologique et cy tologique de la parthénogène de naturelle. Bull. Biol. Fra. Belg. 62

- 1934. La parthénogenèse géographigue. II. Les males triploides d'origine parthénogenètique de Trichoniscus elisabethae Herold. Bull. Biol. Fra. Belg. 68.

- 1938. Les chromosomes des Asellotes. C.R.S.A. Sci. 206.

- 1941. Etude des garnitures chromosomiques de quelques Crustaces isopodes terrestres et d'eandonce europeens. Cytologia 12. 